\title{
Rancang Bangun Sistem Informasi Kepegawaian Berbasis Web di STIE Kesatuan
}

\section{Yanto Hermawan ${ }^{1}$ Ade Mulyana² Nurul Fadillah Rizky I. ${ }^{3}$}

DOI: https://doi.org/10.36339/jaspt.v3i2.420

\section{Abstract}

STIE Kesatuan personnel information system is a problem of special concern in IBI Kesatuan HRD. This is with the ease and effectiveness in processing employee data such as employee data entry, editing employee data, searching employee data, reporting employee data either on screen or printed on paper. There are still many STIE Kesatuan who have not filled in data on manual paper, such as employees who have to fill out a leave form and wait for approval. So to overcome this we need a personnel information system that is better than the previous system, for now the employee information is only from Microsoft Excel and manual data. This study uses a system design implemented with the Diagram Unified Modeling Language (UML). The expected end result is that the employee web-based information system can solve system problems that run more optimally in the employee data entry process. With this research, it is hoped that it can help IBI Kesatuan, especially HRD, to develop a management information system.

Keywords: Information Systems, UML Diagram.

\section{Abstrak}

Sistem informasi kepegawaian STIE Kesatuan merupakan masalah yang menjadi perhatian khusus di HRD IBI Kesatuan. Hal ini dengan kemudahan dan keefektifan dalam mengolah data pegawai seperti entry data pegawai, editing data pegawai, pencarian data pegawai, pelaporan data pegawai baik di layar maupun dicetak di atas kertas. Masih banyak STIE Kesatuan yang belum mengisi data di kertas manual, seperti pegawai yang harus mengisi formulir cuti dan menunggu persetujuan. Maka untuk mengatasi hal tersebut diperlukan suatu sistem informasi kepegawaian yang lebih baik dari sistem sebelumnya, untuk saat ini informasi kepegawaian hanya dari microsoft excel dan data manual. Penelitian ini menggunakan rancangan sistem yang diimplementasikan dengan Diagram Unified Modeling Language (UML). Hasil akhir yang diharapkan adalah sistem informasi pegawai berbasis web ini dapat menyelesaikan permasalahan sistem yang berjalan lebih optimal dalam proses entri data pegawai. Dengan adanya penelitian ini diharapkan dapat membantu IBI Kesatuan khususnya HRD untuk mengembangkan sistem informasi manajemen.

Kata kunci: Sistem Informasi, Diagram UML.
1. Program Studi Sistem Informasi Institut Bisnis dan Informatika Kesatuan

2. Program Studi Sistem Informasi Institut Bisnis dan Informatika Kesatuan

3. Program Studi Sistem Informasi Institut Bisnis dan Informatika Kesatuan, Jalan Ranggagading No. 1 Bogor Indonesia 16123

EMail anto@ibik.ac.id
JAS-PT

JURNAL ANALISIS SISTEM PENDIDIKAN TINGGI ISSN 2580 - 5339 eISSN 2620 - 5718

Volume 3 Nomor 2 DESEMBER 2019 Hal 153 - 160

FORUM DOSEN INDONESIA 


\section{PENDAHULUAN}

Perkembangan akan informasi saat ini berkembang sangat cepat dikalangan masyarakat dan dunia industri, kebutuhan akan informasi semakin meningkat baik dikalangan masyarakat dan dunia industri itu sendiri. Hal ini berkaitan dengan kegiatankegiatan yang sering dilakukan secara manual dan kini akan semakin lebih cepat dan tepat jika dilakukan dengan bantuan sebuah aplikasi. Selama ini, dalam pengelolaan kepegawaian STIE Kesatuan masih mengalami beberapa kendala diantaranya HRD membutuhkan waktu yang lama dalam menyeleksi berkas pegawau karena tidak adanya record data calon pegawai, rekapitulasi data karyawan masih manual mengakibatkan terjadinya tidak keakuratan data yang ada dan tidak terupdate secara cepat. Oleh karena itu akan dirancang suatu sistem informasi kepegawaian untuk menggantikan sistem yang lama agar seluruh proses kepegawaian yang ada di STIE Kesatuan dapat dilakukan dengan mudah, cepat dan akurat.

Sistem informasi adalah kombinasi antara prosedur kerja, informasi, orang, dan teknologi informasi yang diorganisasikan untuk mencapai sebuah tujuan dalam organisasi. Alter (1992) dapat diartikan sistem informasi adalah sebuah kombinasi teknologi informasi serta prosedur yang berhubungan dalam mengelola sebuah data yang akan diolah menjadi sebuah informasi yang berguna bagi sebuah organisasi untuk mencapai tujuan. Kepegawaian merupakan sebuah kegiatan mengelola sumber daya manusia pada sebuah organisasai. Pada hakikatnya kepegawaian adalah sebuah kegiatan mengelola kepangkatan, kewajiban, pembinaan pegawai serta hak yang harus didapat oleh pegawai tersebut. Mengelola tenaga kerja haruslah mengelola karena kedunya merupakan sebuah modal yang sangat di perlukan dalam menunjang kesuksesan sebuah organisasi. Handoko (1989).

Menurut penelitian sebelumnya, sistem informasi kepegawaian mempunyai peranan penting dalam menyiapkan sumber daya manusia secara efektif dan efisien melalui tersedianya informasi sumber daya manusia yang cepat, lengkap, dan akurat. Marimin et all (2006). Sistem informasi kepegawaian merupakan sebuah sistem informasi manajemen yang berfungsi untuk menyediakan berupa akses data-data dan informasiinformasi, mengumpulkan data-data, serta mengelola data sebagai pendukung dalam proses pengambilan. keputusan yang bertujuan untuk meningkatkan kinerja perusahaan terutama dalam bidang kepegawaian Taopik et all (2016). Penelitian serupa pernah dilakukan oleh Lisa et all 2019, untuk membuat sistem informasi kepegawaian yang membahas mengenai pendataan karyawan, pengontrolan jatah cuti, lembur, absensi dan penggajian karyawan. Penelitian lain dilakukan oleh Kristinawati (2014) membuat sistem informasi kepegawaian yang terdiri dari data bagian, jabatan, pegawai kependidikan, pegawai pendidik, pengisian penilaian kependidikan, pengisian nilai pendidik dan rekap absensi, hasil dari penelitian tersebut mempermudah HRD dalam mengupdate informasi data pegawai dan memudahkan dalam mengontrol kinerja pegawai. Sistem informasi kepegawaian dapat meliputi pendataan pegawai, pengolahan data informasi terkait pegawai untuk menghasilkan informasi yang cepat, lengkap, dan akurat dalam rangka mendukung administrasi

JAS-PT

JURNAL ANALISIS SISTEM PENDIDIKAN TINGG

ISSN $2580-5339$

elSSN $2620-5718$

Volume 3

Nomor 2

DESEMBER 2019

Hal 153 - 160

FORUM DOSEN INDONESIA kepegawaian.

\section{METODE PENELITIAN}

Adapun tahapan-tahapan dalam pengumpulan data sebagai berikut:

1. Observasi Pada tahap ini penulis melakukan pengamatan langsung SOP yang ada di STIE Kesatuan. 
2. Wawancara Pada tahap ini penulis melakukan wawancara untuk pengumpulan informasi mengenai data-data yang berkaitan dengan penelitian.

3. Studi Pustaka Pada tahap ini penulis mencari sumber referensi seperti bukubuku, jurnal maupun SOP yang ada di STIE Kesatuan yang berkaitan dengan penelitian.

Metode pengembangan sistem yang digunakan penulis dalam membuat sistem ini yaitu metodologi iterasi. Metodologi iterative adalah suatu model pengembangan sistem yang mengkombinasikan proses-proses pada model air terjun dan iterative dengan prototype. Adapun beberapa tahapan dalam metode iterasi ini diantaranya:

1. Tahap Perencanaan. Pada tahap perencaan ini yang dilakukan adalah menentukan latar belakang, ruang lingkup dan metode yang digunakan.

2. Tahap Analisis. Pada tahap ini yang dilakukan adalah menganalisis sistem kepegawaian yang telah berjalan dan menganalisis permasalahan yang terjadi saat ini.

3. Tahap Perancangan. Dari analisis permasalahan yang ada, dilakukan perancangan sistem yang baru sesuai kebutuhan perusahaan.

4. Tahap Implementasi. Pada tahap implementasi ini dibuat sistem aplikasi dan database menggunakan PHP dan MySQL.

5. Tahap Pemeliharaan. Tahap ini mencakup seluruh proses yang diperlukan untuk menjamin kelancaran, dan penyimpanan sistem yang baru.

Perancangan dan pembuatan sistem pembangunan sistem kepegawaian ini dengan metode ini menggunakan beberapa software pendukung. Diantaranya perangkat lunak yang digunakan, seperti ditunjukkan pada Tabel 1 dibawah ini

Tabel 1 Perangkat lunak yang digunakan

\begin{tabular}{|c|l|l|}
\hline No & \multicolumn{1}{|c|}{ Perangkat Lunak } & \multicolumn{1}{|c|}{ Deskripsi } \\
\hline 1 & $\begin{array}{l}\text { Microsoft Windows } 7 \\
\text { Ultimate }\end{array}$ & Sistem operasi yang digunakan \\
\hline 2 & User interface(UI) & $\begin{array}{l}\text { Software yang digunakan untuk menulis coding } \\
\text { program pada tahap implementasi dan membuat } \\
\text { tampilan user interface }\end{array}$ \\
\hline 3 & Notepad ++ & Software yang digunakan untuk memberikan coding \\
\hline 4 & Xampp 1.7 & $\begin{array}{l}\text { Software yang didalamnya terdapat MySql, } \\
\text { sebagai pengolah data, Apache Server sebagai } \\
\text { local server yang diintegrasikan dengan Hypertext } \\
\text { Prepocessor (PHP) }\end{array}$ \\
\hline 5 & $\begin{array}{l}\text { Microsoft Office Excel } \\
2010\end{array}$ & $\begin{array}{l}\text { Software yang digunakan untuk perhitungan bobot } \\
\text { dari data yang diperoleh }\end{array}$ \\
\hline 6 & $\begin{array}{l}\text { Microsoft Office Word } \\
2010\end{array}$ & $\begin{array}{l}\text { Software yang digunakan untuk membuat tulisan } \\
\text { ilmiah }\end{array}$ \\
\hline 7 & $\begin{array}{l}\text { Microsoft Office Power } \\
\text { Point 2010 }\end{array}$ & Software yang digunakan untuk presentasi \\
\hline 8 & $\begin{array}{l}\text { Microsoft Office Visio } \\
2010\end{array}$ & $\begin{array}{l}\text { Software yang digunakan untuk mendesain diagram } \\
\text { dan flowchart }\end{array}$ \\
\hline
\end{tabular}

\section{HASIL DAN PEMBAHASAN}

\section{Analisis kebutuhan}

Analisis kebutuhan dilakukan untuk mendefinisikan kebutuhan-kebutuhan sistem,

JAS-PT

JURNAL ANALISIS SISTEM PENDIDIKAN TINGGI ISSN 2580 - 5339 eISSN $2620-5718$

Volume 3

Nomor 2

DESEMBER 2019

Hal 153 - 160

FORUM DOSEN INDONESIA 
meliputi: kebutuhan fungsional dan analisa kebutuhan pengguna.

\section{Analisis kebutuhan fungsional}

Kebutuhan fungsional sistem mendefinisikan hal-hal yang dibutuhkan oleh sistem yang akan dibangun, antara lain:

a. Kemampuan untuk melakukan input, edit, dan hapus data sistem kepegawaian

b. Kemampuan untuk memfasilitasi proses rekap data kepegawaian.

\section{Analisis kebutuhan pengguna}

Pengguna sistem kepegawaian terdiri yaitu Bagian HRD yang mengelola seleuruh kepegawian yang ada di STIE Kesatuan, yang mempunyai hak untuk menginput data.

\section{Analisis masukan dan keluaran sistem}

Masukan yang dibutuhkan oleh sistem kenaikan jabatan fungsional dosen yaitu :

Data-data kepegawaian serta berkas-berkas.

\section{Kebutuhan Non Fungsional}

Kebutuhan non fungsional adalah tipe kebutuhan yang berisi properti perilaku yang dimiliki oleh sistem. Kebutuhan nonfungsional yang telah diuraikan kemudian dirangkum dalam Tabel 1 dibawah ini.

Tabel 2. Kebutuhan Non Fungsional
\begin{tabular}{|c|l|}
\hline Performance & $\begin{array}{l}\text { Diharapkan dapat membantu dalam proses penginputan data data } \\
\text { dan berkas berkas pegawai. } \\
\text { Diharapkan dapat mempermudah dalam proses pencarian data } \\
\text { karyawan baru. }\end{array}$ \\
\hline Information & $\begin{array}{l}\text { Data dengan informasi laporan pegawai dan laporan cuti serta izin } \\
\text { menjadi lebih update. } \\
\text { Diharapkan dapat memberikan informasi tentang data kepegawaian. }\end{array}$ \\
\hline Economic & $\begin{array}{l}\text { Diharapkan sistem dapat meminimalisir kerugian } \\
\text { dikarenakan kurang updatenya informasi. }\end{array}$ \\
\hline Control & Diharapkan sistem dapat mengkontrol data dan berkas pegawai \\
\hline Efficiency & $\begin{array}{l}\text { Dapat mengurangi beban kerja pada saat proses seleksi berkas } \\
\text { karyawan baru sehingga nantinya lebih cepat dalam mencari } \\
\text { dokumentasi. }\end{array}$ \\
\hline $\begin{array}{l}\text { Diharapkan dapat mempermudah pegawai dalam proses pengajuan } \\
\text { izin. } \\
\text { Sistem dapat memberikan data-data karyawan yang lengkap dan } \\
\text { akurat, sehingga dapat membantu HRD. }\end{array}$ \\
\hline
\end{tabular}

Diagram Konteks. Diagram konteks adalah diagram tingkat atas, yaitu diagram secara global dari sebuah sistem informasi kepegawaian yang menggambarkan alur data ke dalam maupun luar dari sebuah entitas. Adapun diagram konteks dapat dilihat pada dibawah ini.

JAS-PT

JURNAL ANALSIS SISTEMPENDIDIKAN TINGG

ISSN $2580-5339$

elSSN $2620-5718$

Volume 3

Nomor 2

DESEMBER 2019

Hal 153 - 160

FORUM DOSEN INDONESIA

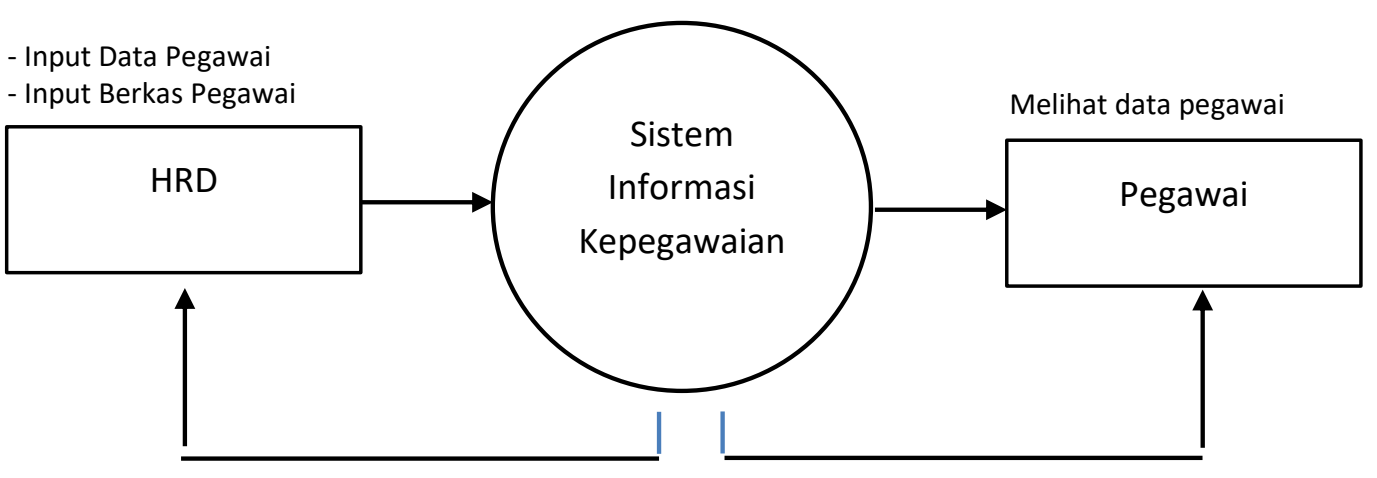




\section{Pelaku Sistem (Aktor)}

Pelaku Sistem (Aktor) dapat dilihat pada Tabel 3

Tabel 3 Pelaku Sistem (Aktor)

\begin{tabular}{|l|l|}
\hline \multicolumn{1}{|c|}{ Aktor } & \multicolumn{1}{c|}{ Deskripsi } \\
\hline HRD & $\begin{array}{l}\text { Pengelola Sistem yang mempunyai hak untuk } \\
\text { mengelola/input jenjang kepangkatan akademik sistem }\end{array}$ \\
\hline PEGAWAI & Melihat isian data yang telah diinputkan \\
\hline
\end{tabular}

\section{Tampilan Antarmuka Beranda Unit HRD}

Tampilan antarmuka beranda unit HRD Merupakan halaman pertama ketika sistem kepegawaian ini dibuat, tampilan halaman home dapat dilihat pada gambar 1 dibawah ini.

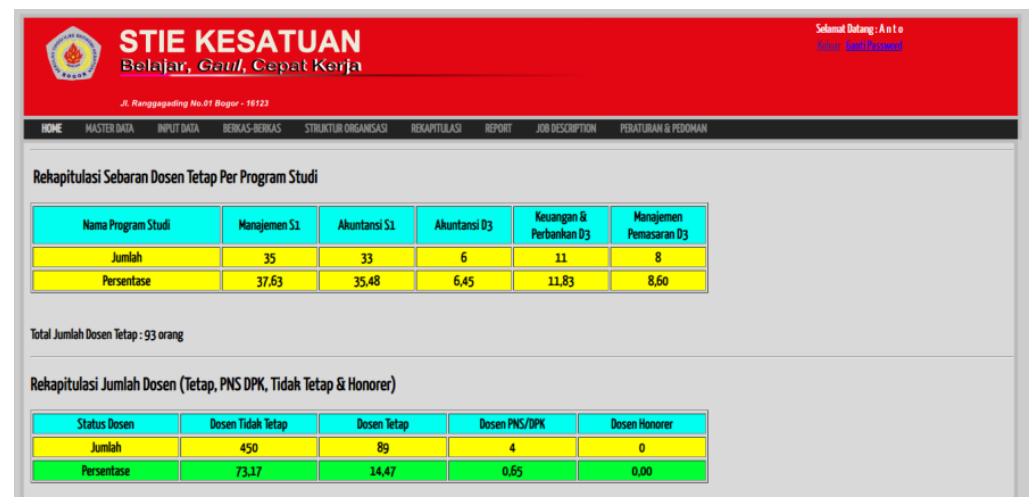

\section{Tampilan Antarmuka Daftar Pegawai}

Gambar 1 Tampilan Beranda Sistem Kepegawaian

Tampilan antarmuka data data pegawai unit HRD merupakan halaman yang akan memberikan kita data data pegawai secara lengkap, namun data data yang diperlukan adalah data data dari setiap pegawai yang ada. Rampilan halaman input daftar dapat dilihat pada gambar 2 dibawah ini.



\section{Tampilan Antarmuka Input Biodata Pegawai}

Tampilan antarmuka input data data pegawai unit HRD merupakan halaman yang akan memberikan kita data data pegawai secara lengkap, dari foto pegawai, berkas ktp, kartu keluarga dan lainnya, namun data yang diperlukan adalah data dari setiap pegawai yang ada STIE Kesatuan. Tampilan halaman input biodata pegawai dapat dilihat pada gambar 3 dibawah ini.

JAS-PT

JURNAL ANALISIS SISTEM PENDIDIKAN TINGGI ISSN $2580-5339$ elSSN $2620-5718$ Volume 3 Nomor 2 DESEMBER 2019 Hal $153-160$

FORUM DOSEN INDONESIA 


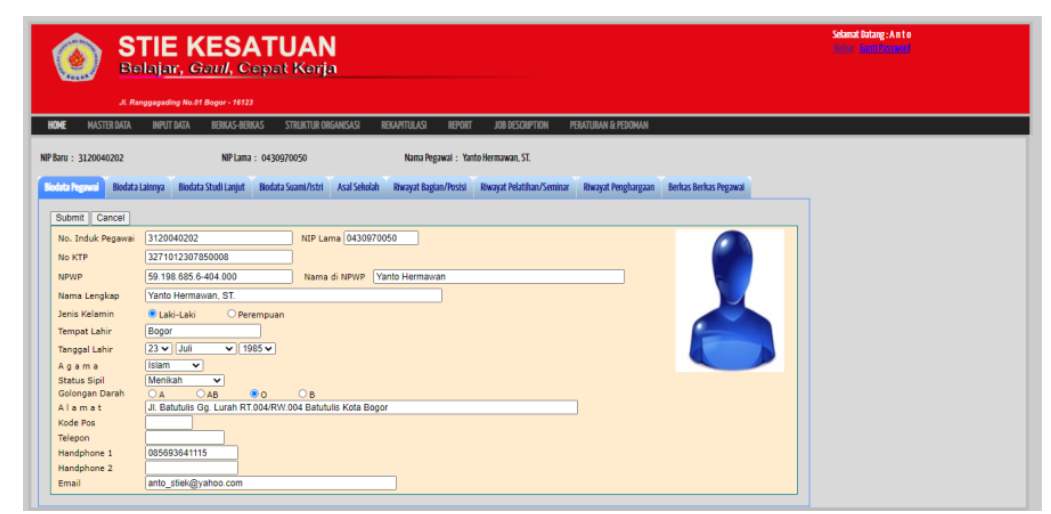

Gambar 3 Tampilan Input Data Pegawai Sistem Kepegawaian

\section{Tampilan Report Biodata Pegawai}

Tampilan report data pegawai unit HRD merupakan halaman yang akan memberikan kita data pegawai secara lengkap, dari foto pegawai, berkas ktp, kartu keluarga dan lainnya, namun data yang diperlukan adalah data dari setiap pegawai yang ada STIE Kesatuan. Tampilan halaman input biodata pegawai dapat dilihat pada gambar 4 dibawah ini.

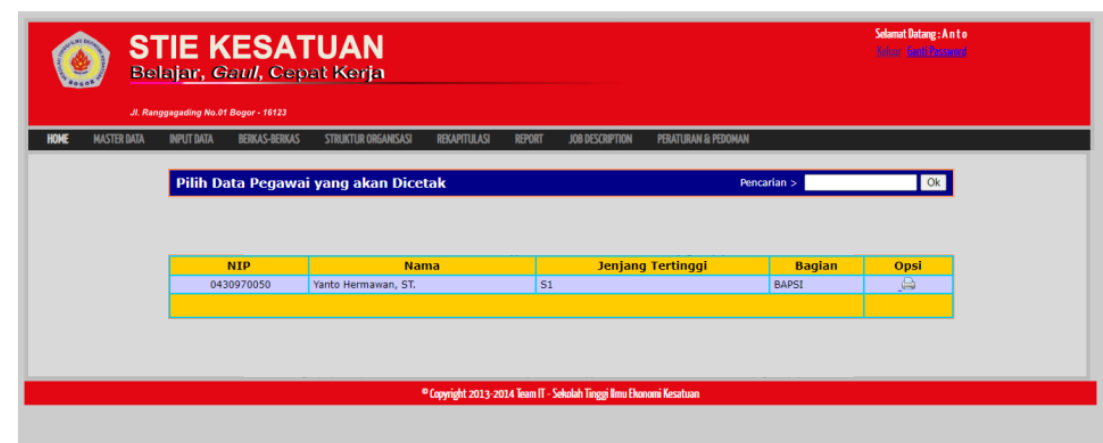

Gambar 4 Tampilan Report Data Pegawai Sistem Kepegawaian

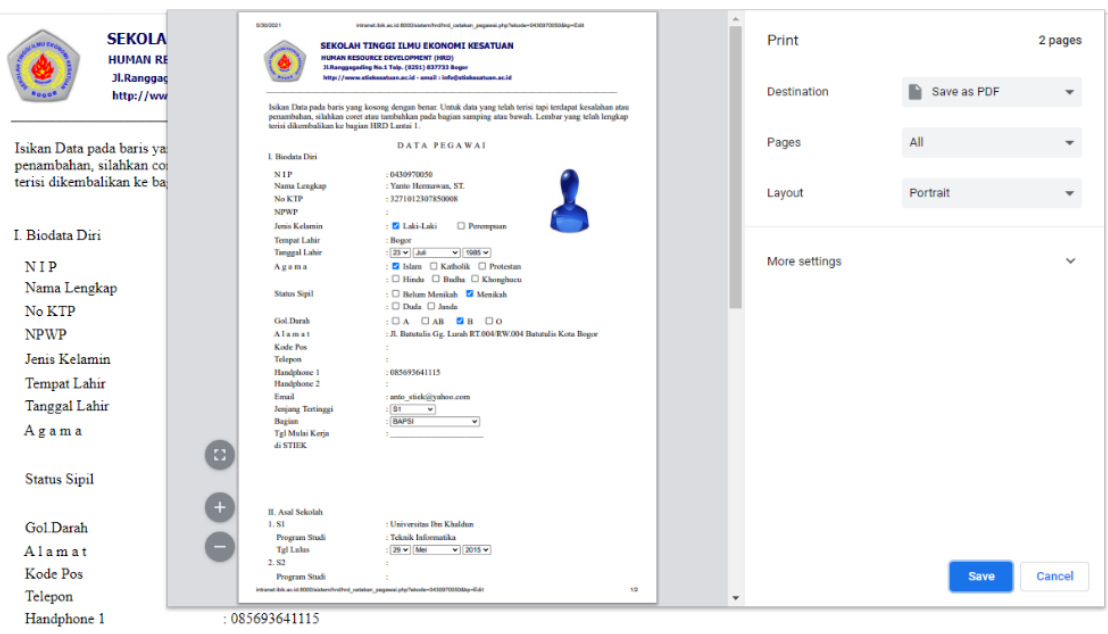

JAS-PT

JURNAL ANALISIS SISTEM PENDIDIKAN TINGGI ISSN $2580-5339$ eISSN $2620-5718$

Volume 3

Nomor 2 DESEMBER 2019

Hal $153-160$

Gambar 5 Tampilan Print Report Data Pegawai Sistem Kepegawaian

\section{Testing Sistem}

Pengecekan sistem merupakan pengukuran suatu aplikasi yang telah dibuat dijalankan menggunakan web browser apakah aplikasi tersebut telah berjalan dengan sesuai 
kebutuhan yang ada. Dan Pengecekan ini juga dilakukan untuk mengetahui apakah aplikasi berjalan sudah sesuai tujuan .

1. Pengecekan Struktural Sistem

Pengecekan struktural adalah pengecekan yang dilakukan untuk mengetahui sistem yang dibuat sudah sesuai dengan rancangan sebelumnya. Tahapan pengecekan ini dilakukan dengan menampilkan form yang ada dalam sistem, pengecekan struktural seperti ditunjukan pada Tabel 4 dibawah ini.

Tabel 4 Pengecekan Struktural Sistem

\begin{tabular}{|c|c|}
\hline Form & Hasil \\
\hline Home & Sesuai \\
\hline Login & Sesuai \\
\hline Tambah Daftar Pegawai & Sesuai \\
\hline Upload Berkas & Sesuai \\
\hline Rekapitulasi & Sesuai \\
\hline
\end{tabular}

2) Pengecekan Fungsional

Pengecekan fungsional dilakukan dengan menggunakan fungsi-fungsi yang ada pada setiap form, pengecekan fungsional seperti ditunjukan pada Tabel 5.

Tabel 5 Pengecekan fungsional

\begin{tabular}{|c|c|}
\hline Form & Hasil \\
\hline Home & Berfungsi \\
\hline Login & Berfungsi \\
\hline Tambah Daftar Pegawai & Berfungsi \\
\hline Rekapitulasi & Berfungsi \\
\hline
\end{tabular}

\section{PENUTUP}

Berdasarkan rancang bangun sistem kepegawaian berbasis web pada STIE Kesatuan, penulis dapat mengambil kesimpulan sebagai berikut;

1. Sistem dapat mempermudah HRD untuk mendapatkan laporan data pegawai dengan lebih cepat dan akurat.

2. Dengan adanya fitur rekrutmen dapat membantu mempermudah HRD dalam menyimpan record data calon pegawai sehingga proses seleksi rekrutmen lebih cepat.

\section{DAFTAR PUSTAKA}

Ramadhan Taopik, Rinda Cahyana, 2016, Pengembangan Sistem Informasi Kepegawaian pada Dinas Perindustrian Perdagangan dan Pengelolaan Pasar Kabupaten Garut, JurnalSTT-Garut.

Marimin, Hendri Tanjung, Haryo Prabowo 2006. Sistem Informasi Manajemen SumberDaya Manusia. Grasindo, Bogor.

Monica Lisa, Permata Sari, Intan. 2019. Sistem Informasi Kepegawaian Berbasis Desktoppada PT Indomarco Adi Prima Palembang.

E. Kristinawati, 2014. Sistem Informasi Kepegawaian Berbasis Web Sebagai PendukungKeputusan Pimpinan Di Stekom Semarang.

Alter, S. "Information System: A Management Perspective." San Francisco: The Benjamin/Cummings Publishing Company, Inc. 1992

Hani Handoko,. "Manajemen Personalia dan Sumberdaya Manusia." Yogyakarta: BPFEYogyakarta. 1989

Purba, J. H. V., Ratodi, M., Mulyana, M., Wahyoedi, S., Andriana, R., Shankar, K., \&

JAS-PT

JURNAL ANALISIS SISTEM PENDIDIKAN TINGG ISSN $2580-5339$ elSSN $2620-5718$

Volume 3

Nomor 2

DESEMBER 2019

Hal $153-160$

FORUM DOSEN INDONESIA 
Nguyen, P. T. (2019). Prediction Model in Medical Science and Health Care. International Journal of Engineering and Advanced Technology, 8, 815818.

Retna, D. W., \& Sulistiono, A. (2014). PENGARUH KUALITAS PRODUK DAN KUALITAS PELAYANAN TERHADAP KEPUASAN PELANGGAN. Jurnal IImiah Manajemen Kesatuan, 2(3).

Sulistiono, S., \& Mashadi, M. (2018). Diversifikasi Perkebunan Kopi Sebagai Tempat Wisata Di Pangalengan Kabupaten Bandung. Jurnal Abdimas, 2(1), 038-042.

Yudhistira, L. D., Mulyana, M., \& Mashadi, M. (2013). TINJAUAN PELAYANAN PRIMA PADA TOYOTA SETIAJAYA DALAM MENARIK KONSUMEN. Jurnal Online Mahasiswa-Manajemen, 1(1).

JAS-PT

JURNAL ANALISIS SISTEM PENDIDIKAN TINGG

ISSN $2580-5339$

eISSN $2620-5718$

Volume 3

Nomor 2

DESEMBER 2019

Hal $153-160$

FORUM DOSEN INDONESIA 